Benny Geys *

Jan Vermeir **

The Political Cost of Taxation:

New Evidence from German Popularity Ratings

* WZB

${ }^{* *}$ Vrije Universiteit Brussel

SP II $2008-06$

February 2008

ISSN Nr. $0722-6748$

Research Area

Markets and Politics

Research Unit

Market Processes and Governance
Schwerpunkt

Märkte und Politik

Abteilung

Marktprozesse und Steuerung 
Zitierweise/Citation:

Benny Geys and Jan Vermeir, The Political Cost of Taxation: New Evidence from German Popularity Ratings, Discussion Paper SP II 2008 - 06,

Wissenschaftszentrum Berlin, 2008.

Wissenschaftszentrum Berlin für Sozialforschung gGmbH,

Reichpietschufer 50, 10785 Berlin, Germany, Tel. (030) 25491 - 0

Internet: www.wzb.eu 


\title{
The Political Cost of Taxation: New Evidence from German Popularity Ratings
}

\author{
by Benny Geys and Jan Vermeir *
}

Previous studies indicate that higher tax burdens reduce incumbents' popularity and re-election odds. The present paper offers a new test of this relation for German data. Our findings indicate that taxation indeed negatively affects German federal government approval ratings, in line with previous international research. Nonetheless, the government's popularity losses do not necessarily translate into comparable gains in the opposition's popularity. In fact, the opposition may even lose support when there is 'divided government' (i.e. when it has some power over policies). Finally, we find some (albeit weak) evidence that the costs of taxation are limited to the tax burden imposed by the federal government and do not extend to taxes levied at lower levels of government.

Keywords: Taxation, government approval, popularity function, Germany

\section{ZUSAMMENFASSUNG}

\section{Besteuerung und Popularität von Politikern: Neue Ergebnisse für die Deutsche Bundesregierung 1978-2003}

Bisherige Untersuchungen zeigen, dass höhere steuerliche Belastungen die Beliebtheit und Wiederwahlchancen von Amtsträgern mindern. Das vorliegende Papier überprüft diese Beziehung erneut anhand von Daten für Deutschland. Übereinstimmend mit internationalen Forschungsergebnissen zeigen unsere Resultate, dass Besteuerung die Zustimmung zur Arbeit der Bundesregierung tatsächlich negativ beeinflusst. Der Popularitätsverlust der Regierung setzt sich jedoch nicht notwendigerweise in vergleichbare Gewinne der Opposition um. Vielmehr ist im Falle von „Divided Government“ (d.h. die Opposition trägt ebenfalls Regierungsverantwortung) ein Verlust an Unterstützung der Opposition möglich. Schließlich finden wir Beweise (wenn auch schwache), dass die Kosten der Besteuerung durch die von der Bundesregierung auferlegte steuerliche Belastung begrenzt sind und nicht von Steuern beeinflusst werden, die von nachrangigen Regierungsebenen erhoben werden.

\footnotetext{
Jan Vermeir thanks FWO-Vlaanderen for financial support. Both authors appreciate helpful comments from participants of the 1st World Public Choice Societies Meeting in Amsterdam (March/April 2007), the annual meeting of the Verein für Sozialpolitik in Munich (October 2007) as well as Niclas Berggren, Ivo Bischoff, Michael Funk, Beate Jochimsen, Gebhard Kirchgässner, Zuzana Murdoch, Hermann Schmitt, Kelly Shue, Daniel Sturm, Linda Veiga and one anonymous referee. We are also indebted to Van Anh Vuong, Martina Grunow, Wolfram Schwabbacher and Sebastian Thomasius for excellent research assistance.
} 


\section{Introduction}

Scholarship in political science and economics has devoted substantial attention to explaining variations over time and space in election results and popularity ratings. ${ }^{1}$ This literature on so-called vote and popularity functions (or VP functions) (for reviews, see Paldam, 1991; Nannestad and Paldam, 1994) has also addressed the effects of fiscal policies on politician's popularity or re-election chances because, arguably, fiscal policies are a sensitive issue for voters. Findings from US nation-wide surveys corroborate the latter idea by showing that even when open-ended questions are used, taxation was the $4^{\text {th }}$ most important issue in shaping people's voting decisions for the US Congress elections in 2002, after the economy (and employment), education policy and international terrorism (e.g. NPR/Kaiser/Kennedy School poll, 23-27 October 2002; Pew Research Center/Princeton Survey Research Associates poll, 30 October-2 November 2002). Taxation generally also features prominently in candidates' election programs and discussions thereof in the media (e.g. Hossain, 2007a, b). Hence, it can be expected to influence voters' assessment of incumbents and become reflected in their popularity ratings and election results.

The first studies assessing the effects of taxation on politicians' popularity and/or reelection odds already appeared some 40 years ago (e.g. Pomper, 1968; Turett, 1971). Nevertheless, as shown below, the findings do not unequivocally support the existence of a (hypothesised) negative relation between taxation and politicians' popularity and/or vote share at elections. The present paper adds to this literature in three ways:

Firstly, we analyse the taxation-popularity nexus using German data. This is important since most scholars investigated the US or UK. Given the ambiguity of previous findings, an extension to different settings may generate new insights. Thus far, Frey and Schneider (1981) and Cusack (1999) are the only two German analyses including a measure of taxation, but they restrict themselves to direct income taxation. In the present paper, we take a broader perspective by regarding the overall tax burden (as well as its constituent parts).

Secondly, we not only gauge the effect of taxation on incumbents, but also on the opposition. While some scholars assess the effects of economic variables on opposition popularity (e.g. Miller and Mackie, 1973; Feld and Kirchgässner, 2000), the potential effects of taxation on the opposition have received much less attention (for exceptions, see Paldam and Schneider, 1980; Landon and Ryan, 1997). Nonetheless, analysing opposition popularity may reveal additional information since a loss of popularity for the government might - but need not necessarily - translate into increased popularity of the opposition.

Thirdly, we test the proposition that voters consider only the tax burden due to the incumbent at a certain level of government (e.g. the federal-level tax burden for the federal government). Such a focus may result because this is the tax burden over which the incumbent has the most direct influence through its policies. To the best of our knowledge, this has not been addressed in previous work.

Understanding what drives popularity between elections and outcomes on Election Day are different though complementary projects (we return to this discussion below). The present paper concentrates on popularity between elections and thus focuses more on the 'political' or 'popular' costs of taxation than the 'electoral' costs thereof. 
The outline of the paper is as follows. Section 2 brings forward the theoretical background for our main hypotheses, while section 3 discusses existing (international) work on VP-functions in Germany and the ('political' and 'electoral'; cfr. footnote 1) cost of taxation. Section 4 describes the evolution of the total tax burden and government and opposition popularity in Germany over the period 1978-2003. In section 5 , the latter two data series are brought together to assess the political cost of taxation for the government and opposition in Germany. Section 6 concludes.

\section{Theoretical background and hypotheses}

The theoretical basis for most studies on VP-functions is the 'responsibility hypothesis' (cfr. Nannestad and Paldam, 1994). This states that voters assess the performance of their political leaders and hold them responsible for the state of the country's affairs. The basic idea of this proposition can be rooted in behavioural assumptions on voter rationality (cfr. Downs, 1957; Key, 1966). Still, more recently, models based on rational expectations have provided a firmer theoretical basis for the 'responsibility hypothesis'. In the competency model of Rogoff and Sibert (1988), for example, parties differ in their ability to generate desired (economic) outcomes. While this competency cannot be directly observed by the electorate, it can be judged by evaluating past (economic) outcomes. Hence, the more positive the voter evaluates the performance of its political leaders, the more competent these leaders are assumed to be and the more popular they become. Based on this 'responsibility hypothesis', positive economic developments (such as higher growth, lower inflation and lower unemployment) have been argued to increase incumbent's popularity (and election prospects). By simple extension of this model, political leaders might also be held responsible for tax policies. The reason is that voters care about taxes (as illustrated by the survey research cited above) and are therefore likely to be influenced by them in their assessment of their political leaders. Moreover, a higher tax burden is generally seen as 'bad' since each voter rather pays less than more taxes. Hence, a first hypothesis can be derived as follows:

Hypothesis 1: Increases in the tax burden negatively affect government popularity, while decreases positively affect government popularity.

It should be noted that the above line of argument first of all assumes that voters are backward-looking (using historical developments to assess politicians). While one might argue that rational voters should be prospective rather than retrospective at election time, this argument is less persuasive for popularity ratings. Indeed, in elections one chooses a future government (supporting a prospective attitude), while in popularity polls people think less about future governments and simply give their 'gut feeling' about the situation right now (supporting a retrospective view) (Paldam, 1991: 16). Still, Nannestad and Paldam (1994) and Lewis-Beck and Paldam (2000) show that in reality the differences between both approaches are small because the relevant expectations tend to be rather static. Moreover, previous analyses illustrate that voters react more to past changes than to forecasts (e.g. Lanoue, 1994; Veiga and Veiga, 2004), supporting our use of historical (rather than predicted) economic indicators. Secondly, the reasoning underlying Hypothesis 1 assumes sociotropic rather than egotropic voters: i.e. people react more to the state of the country at large than their own pocketbook. This follows the consensus among most scholars that national (sociotropic) conditions 
are most relevant (e.g. Kinder and Kiewiet, 1979; Fiorina, 1981; Jacobson, 1983; Rattinger, 1986; Lewis-Beck, 1988; Feldman and Conley, 1991).

Importantly, the opposition may also - at least partly - be held responsible for enacted policies (or failing to obstruct undesirable policies). In the German setting analysed here, the reason for such an effect can be found in the co-decision procedures at the German federal level between the Bundestag and Bundesrat. The Bundestag consists of federally elected politicians while the Bundesrat houses representatives from the Länder (i.e. elected at the Land-level). As many types of legislation need the approval of both political bodies, the Bundesrat holds significant power in the legislative process. This is important since the Bundesrat often has a majority of members allied to parties which are in the opposition at the federal level (this was effectively the case over most of the period studied here). Under such 'divided government', the opposition can block (or, at least, postpone) legislative proposals brought forward by the government. Hence, assuming the German voter understands the co-decision procedures and has some information on the distribution of power in both Bundestag and Bundesrat, (s)he may hold the opposition partly responsible for undesirable policies when this opposition has significant political power via a majority position in the Bundesrat (i.e. under 'divided government'). ${ }^{2}$ When the government also controls a majority in the Bundesrat (i.e. under 'unified government'), the opposition has only limited political power and should not be punished for undesirable policies. In fact, a higher tax burden may in such a situation even be beneficial for the opposition and lead it to become more popular through voters' hopes for different policies under the current opposition. This leads to the following hypotheses:

Hypothesis 2a: Increases in the tax burden are likely to negatively affect opposition popularity under 'divided government' (when the opposition has political power in at least one government body).

Hypothesis 2b: Increases in the tax burden are likely to have no or a positive effect on opposition popularity under 'unified government' (when the government controls all government bodies).

Finally, the total tax burden facing (German) citizens consists of taxes decided upon at three levels of government: federal, regional and local. However, one might argue that voters should primarily take into account the tax burden due to the incumbent at a certain level of government. The reason is that, for example, federal politicians cannot be held responsible for local decisions since they have no say in the decision-process. Nonetheless, decisions by the federal government may sometimes indirectly affect regional (or local) tax burdens. For example, reductions in federal grants to lower-level governments may invoke local tax increases. Still, the impact of such events on federal government popularity is likely to be small for two reasons. Firstly, voters need to be aware (and believe) that the increased local tax burden is due to federal government policy changes. Secondly, unless the federal policy change has an impact on tax policies of all local governments, the effect in one particular municipality or state is unlikely to affect overall federal government popularity. Consequently, we formulate the following hypothesis:

2 We are grateful to Gebhard Kirchgässner for drawing our attention to this issue. Note that in most countries opposition parties have the ability to propose amendments or are represented in policy committees. As such, they play some role in the proceedings and the argument made here may therefore transcend our German setting. 
Hypothesis 3: Voters only punish/reward the federal government (opposition) for changes in the tax burden at the federal level, and do not take into account the tax burden imposed by lower levels of government.

\section{Review of the literature}

\subsection{VP function analyses in Germany}

Various scholars have previously analysed the determinants of popularity ratings (or election results) of the German government, Chancellor or political parties. Like most of the VP-function literature, the majority of these studies concentrate on the effect of objective or subjective economic conditions (i.c. unemployment, income and inflation). ${ }^{3}$ In one of the first studies on Germany, Kirchgässner $(1976,1977)$ shows that inflation and unemployment significantly reduce German government popularity - with unemployment usually having a stronger impact (see also Frey and Schneider, 1981). ${ }^{4}$ Building on this finding, Rattinger (1979) and Feld and Kirchgässner (2000) explicitly concentrate on the effects of unemployment. Rattinger (1979) thereby makes a distinction between structural and cyclical unemployment. His results show that structural unemployment increases the vote share of the traditional parties (CDU and SPD) while cyclical unemployment benefits the Social-Democrats (SPD) and hurts the Christian-Democrats (CDU). Feld and Kirchgässner (2000) distinguish between official and hidden unemployment during the Kohl-era (i.e. 1984-1996) and find that both significantly negatively affect government popularity, while raising that of the opposition (especially in the former East-German states, where hidden unemployment was more of a problem).

Still, there is no uniform support in German studies for the thesis that economic conditions influence government popularity (or election results). For example, Norpoth and Yantek (1983) and Schimek (1986) find no relation between unemployment and inflation and German government popularity in the 1970s. More recent studies by Rattinger and co-authors similarly do not always retrieve an impact of economic conditions on individual voting behaviour (e.g. Rattinger, 2000; Maier and Rattinger, 1999, 2004; Kellerman and Rattinger, 2006). Anderson (1995a, 93) does not negate the effect of economic variables but argues that their effect is strongly 'mediated by the choices available to citizens to express their discontent'. In line with this argument, his empirical analysis illustrates that the effect of macro-economic performance on government popularity is stronger when the effective number of parties in the political system is higher. Moreover, Anderson (1995b, Ch. 6) shows that economic performance may affect the political support of various parties in a coalition government differently (depending on the coalition partners' perceived issue competences).

Finally, it is important to note that some scholars have gone beyond economic variables as potential explanations of German government popularity. Norpoth and Goergen (1990) and Goergen and Norpoth (1991), for example, introduce the notion of a

3 Two studies explaining German government (or Chancellor) popularity introduce a tax variable, namely Frey and Schneider (1981) and Cusack (1999). Their results are presented in section 2.2.

4 Kirchgässner's later work devoted much attention to the causal nature of this relation and illustrates that individual voting intentions in Germany are 'strongly influenced by the perceived economic situation’ (Kirchgässner, 1985b, 155; see also Kirchgässner, 1985a, 1986). 
'popularity credit' which governments enjoy at the beginning of their term. This postelection boom in popularity is, in contrast to the (closely related) 'honeymoon effect' introduced by Mueller (1970), not 'condemned to vanish' as 'by some natural law', but depends on how the government handles the 'problems that brought down its predecessor' (Goergen and Norpoth, 1991, 196). Anderson (1996) illustrates that the popularity of the governing party in Germany is significantly inter-related with the popularity of its leader (i.e. the Chancellor). A more popular leader is able to prop up the popularity of his/her party (although (s)he is in turn affected by the (un)popularity of his/her party). Gschwend and Norpoth (2000) and Norpoth and Gschwend (2003) also find a relation between chancellor popularity and the vote share of the government parties (though, in contrast to the previously mentioned studies, their model is built with the explicit aim to predict future election outcomes).

\subsection{The cost of taxation to politicians}

The potential costs of taxation to politicians are twofold. Firstly, it may make them unpopular. Secondly, it might increase the probability of their dismissal during the next election. These 'political' (in terms of popularity) and 'electoral' costs (in terms of reelection odds or vote shares) are often not clearly distinguished. Nonetheless, there is an obvious qualitative difference between opinion polls and elections (Chapell, 1990; Fox and Phillips, 2003): i.c. being unpopular may make it more difficult to govern, but not being elected makes it impossible. ${ }^{5}$ Hence, although popularity and re-election probabilities are often strongly related (e.g. Sigelman, 1979; Brody and Sigelman, 1983; Vermeir, 2006), understanding what drives popularity between elections and election outcomes on Election Day should be seen as different though complementary projects. Keeping this caveat in mind, the remainder of this section reviews studies assessing both the 'political' and 'electoral' costs of taxation to get a more comprehensive view (and both approaches turn out to be equally inconclusive).

The 'political' and 'electoral' costs of taxation have mainly been investigated by looking at the effect of the total tax burden imposed on the population (measured through total tax revenues). This indicator was first employed in two studies of US gubernatorial election results (Pomper, 1968; Turett, 1971), both of which fail to find a consistent relation between taxation and the incumbent governor's electoral result. This (non-)finding was replicated by Hansen (1999) using US governor popularity ratings rather than election results. Other studies, however, illustrate that the total tax burden does negatively affect the popularity or election results of US governors (e.g. Peltzman, 1992; Lowry et al., 1998; Sobel, 1998; Kelleher and Wolak, 2007) ${ }^{6}$, the US president (e.g. Niskanen, 1975, 1979; Peltzman, 1992; Cuzán and Bundrick, 1999; Geys and Vermeir, 2008; see, however, Hibbs, 2000) and the British government (Pissarides, 1980). ${ }^{7}$ Hence, for both the 'electoral' and the 'political' cost of taxation, evidence appears to be mixed when using the total tax burden as independent variable.

We are grateful to an anonymous referee for this insight.

6 Lowry et al. (1998) and Sobel (1998) show that taxation affects the two main US political parties differently. This effect, however, appears to depend on whether or not there is unified (rather than divided) government (Lowry et al., 1998).

7 A number of studies focus on revenues from direct income taxation only. While Hibbs and Madsen (1981), Frey and Schneider (1981), Happy (1992) and Cusack (1999) show that increasing direct income taxation is politically costly in the US, Canada and Germany, Peltzman (1992) fails to corroborate this using US data. Related, Case (1994) and Besley and Case (1995) show that 
Given the complexity of real world tax systems, however, it may be of interest to distinguish between different types of taxation and assess their relative marginal costs. In doing so, Paldam and Schneider (1980) find that prior to 1970 only direct income taxation (negatively) affects the popularity of Danish parties. During the 1970's, however, both direct and indirect taxation significantly depress popularity. Landon and Ryan (1997) confirm the importance of distinguishing various types of taxation in a study of elections in the Canadian provinces between 1961 and 1990. While revenues from licences, permits and other fees positively influence the incumbent vote share, sales taxes have the reverse effect (direct income taxes and fuel taxes furthermore significantly increase the probability of incumbent defeat). Similarly, tax rate increases are found to be politically more costly for sales taxes than for income or ' $\sin$ ' taxes (i.e. taxes on beer, gasoline and cigarettes) (Kone and Winters, 1993; Stults and Winters, 2005). ${ }^{8}$ Using a comprehensive, single measure of taxation in VP function estimations may thus not be optimal.

Finally, a similar ambiguity as observed above is found in studies examining the 'electoral' cost of introducing new taxes. Whereas Eismeier (1979) finds new taxes to negatively affect the incumbent US governor's vote share, Kone and Winters (1993) cannot confirm this when concentrating on new sales or income taxes in the same setting. Gibson (1994), assessing the UK's poll tax introduction by the Conservative party in 1990, finds a significant negative impact on the Conservative party's vote share in local elections in Birmingham. ${ }^{9}$ The ambiguity observed throughout previous research calls for additional analyses. One such effort for the German setting is presented in the remainder of this paper.

\section{Data description}

\subsection{Popularity ratings: government and opposition}

The 'Politbarometer'-surveys by the Forschungsgruppe Wahlen (Mannheim) ask German citizens how satisfied they are with the performance of their government and opposition roughly every month since 1977 . The relevant questions are as follows:

'Are you rather satisfied or rather dissatisfied with the performance of the German government consisting of [names of parties in government]?'

'And how satisfied or dissatisfied are you with the performance of [names of parties in opposition] in the opposition?' 10

increasing income tax liabilities for high-income earners in the US significantly reduces the incumbent governor's re-election odds.

8 Eismeier (1979) and Johnson et al. (2005) show that tax rate increases in general are politically harmful for the incumbent. Niemi et al. (1995) and MacDonald and Sigelman (1999) illustrate that more numerous tax increases during the legislative term significantly depress the vote or approval rating for the incumbent US governor.

9 Interestingly, politicians believe that introducing new taxes invokes electoral punishment and avoid such actions when elections are imminent (e.g. Mikesell, 1978; Berry, 1988; Berry and Berry, 1992, 1994; Ashworth et al., 2006). Ashworth and Heyndels (2002) also show that changes in the tax structure are less likely in election years.

10 The original German-language questions are: 'Sind Sie mit den Leistungen der Bundesregierung aus (Namen der Koalitionspartner) eher zufrieden oder eher unzufrieden?' and 'Wie zufrieden oder unzufrieden sind Sie mit den Leistungen der (Namen der Oppositionsparteien) in der Opposition?'. 
Respondents can reply on an 11-point scale ranging from -5 to +5 . Following Cusack (1999), we employ the share of positive assessments (i.e. +1 to +5 ) as our measure of government and opposition popularity. ${ }^{11}$ We thereby aggregate the monthly figures to the quarterly level to accommodate the frequency of the main independent variable in the analysis in section 5 (using monthly data would involve duplication of the quarterly taxation data, thus 'artificially' increasing the number of observations).

It should be noted that the popularity ratings employed here do not directly measure vote intention nor Chancellor popularity (the two most common dependent variables in VP-function estimations). However, the above popularity measure is to be preferred in a setting with coalition governments - as is mostly the case in Germany (see also Cusack, 1999, for a similar approach). Firstly, one cannot ask respondents about their intention to vote for the entire coalition (since such a vote is in reality unfeasible, the question would lack credibility). Aggregating vote intentions for all coalition partners is theoretically possible, but may not be a satisfactory reflection of government popularity because people intending to vote for one coalition partner might dislike the current coalition and prefer a different one. Secondly, the Chancellor is a member of one coalition party only, and his/her popularity thus need not fully reflect that of the entire government. These points notwithstanding, our measure of government popularity is strongly correlated with the measures employed in previous research. For example, the correlation between our measure and the popularity of the German Chancellor is very high $(r=0.778)$, while its relation with the intention to vote for either of the government parties is even higher $(r=0.862)$ (Appendix B illustrates that using these alternative dependent variables makes little substantive difference to our results).

Figure 1 contains the popularity ratings for the German government and opposition for the period 1977:1-2003:4. Time is on the X-axis, while the percentage of respondents expressing approval of the government (or opposition) is on the Y-axis. Although data are available for the former Eastern German states as of 1991, we only include respondents of the former West-German states. The reason is a change in the sampling procedures for the Politbarometer surveys in 1996, reducing the 'East-German' sample to $25 \%$ of the 'West-German' one (from equal sample sizes prior to 1996). This adjustment leads to an unwarranted upward shift in the overall popularity ratings in that year since the former East is generally (slightly) less approving than the former West. This re-sampling bias is avoided by concentrating on the 'West-German' data. Still, since the 'dynamics of the two series track very closely' (Cusack, 1999: 642) exclusive reliance on the 'West-German' sample is unlikely to affect the results of our analysis (since only the level of popularity and not its variation is affected by inclusion of the 'East-German' respondents).

Figure 1

about here

11 The question for the opposition slightly altered after 1989. Rather than ask about the entire opposition, the new question inquires separately into the large and small opposition parties. As the post-1989 data do not straightforwardly allow constructing a general opposition-assessment, we rely on the data for the largest opposition partner after 1989. 
Three things are immediately apparent in Figure 1. Firstly, the popularity of both government and opposition has been steadily decreasing in Germany over the period under study. Secondly, significant variation exists around this downward trend. These shocks appear stronger for the government than for the opposition. They also tend to be more outspoken in the second half of our time frame. Finally, and with Hypotheses 2a and $2 \mathrm{~b}$ in mind, Figure 1 does little to indicate that losses in government popularity benefit the opposition. In fact, there rather emerges a common movement in both series (e.g. the early 1990s).

\subsection{Tax burden}

To measure the German tax burden, we rely on quarterly data provided by the National Institute of Statistics (Statistisches Bundesamt) concerning total tax revenues in Germany over the period 1977:1-2003:4 (the most recent data available). To control for seasonal effects (which are strong given the way taxes are collected over the year), we concentrate on year-on-year deviations in real total tax revenues (in 2000 prices). These year-on-year tax revenue changes are portrayed in Figure 2. Before discussing this figure, it should be mentioned that the data refer to West-Germany up to 1990 and cover Germany entirely as of 1991. This change explains the steep increase in tax revenues in 1991 observed in Figure 2. However, the difference in territorial area before and after 1991 implies that the year-on-year change in revenues cannot be evaluated in this year. Hence, we exclude 1991 from our later analysis (though we show the data here to preserve a complete picture).

Figure 2

about here

From Figure 2, it is clear that most of the period up to the end of the millennium is characterized by increasing tax revenues, with some obvious exceptions in, for example, the early 1980s, 1993 and 1997. These developments are clearly affected by the economic situation. For example, the economic downturns in the early 1980s and 1993 reduced real tax revenues. This economic effect obviously needs to be accounted for in the later analysis (cfr. Cameron, 1978; Garrett, 1988; Boix, 1998). Nonetheless, and importantly, German government tax policy decisions also affect the development of total tax revenues. For example, tax revenues decreased strongly in 2001. This drop follows two years with large numbers of new tax regulations, with an overall fiscal effect that the German Ministry of Finance estimated to be strongly negative (see Koester, 2006). A similar relation exists also for the 1997 drop in revenues (following new regulations in 1995 with expected negative fiscal effects) and the rebound in tax revenues towards the middle of the 1980s (following tax reforms with positive expected fiscal effects in 1981-82).

Importantly, our dataset allows a separation of tax revenues from taxes determined at three levels of government: i.e. federal, regional and local (thus allowing a test of 
Hypothesis 3). Specifically, the German federal government is responsible for 'Gemeinschaftsteuern' (66\% of total revenues in 2004) and 'Bundessteuern' (19\%). The former are taxes for which revenues are distributed across various levels of government although, in most cases, the federal government independently decides on the tax legislation (e.g. personal income and corporate taxes). The latter are taxes for which legislation and all revenues are the exclusive domain of the German national government (e.g. toll, alcohol and oil taxes). The regional level in Germany determines the tax legislation and takes in all revenues for 'Ländersteuern' (5\%) (e.g. inheritance and beer taxes). Finally, 'Gemeindesteuern' (10\%) are the exclusive responsibility and revenue source of the local governments (e.g. local property tax, taxes on second residences). This four-way separation of tax revenues is presented in Figure 3 (once again in year-on-year changes).

Figure 3

about here

All four series in Figure 3 follow the general pattern discussed above. Nonetheless, the variation here is mostly larger than that observed for overall revenues. Especially tax revenues at lower levels of government are volatile. Moreover, even though the general pattern is similar for the four series in Table 3, deviations from the trend do not always coincide. Hence, different types of revenues might have diverging effects on government (and opposition) popularity.

\section{Empirical Analysis}

\subsection{Specification}

To assess our three hypotheses, we (separately) estimate a government and opposition popularity function for Germany over the period 1978:1-2003:4. ${ }^{12}$ Our basic specification is:

$$
\begin{aligned}
& \mathrm{P}_{\mathrm{t}}^{\mathrm{G}}=\mathrm{b}_{0}+\mathrm{b}_{1} \mathrm{P}_{\mathrm{t}-1}^{\mathrm{G}}+\mathrm{b}_{2} \mathrm{X}_{\mathrm{t}}+\mathrm{b}_{3} \mathrm{REV}_{\mathrm{t}}+\mathrm{e}_{\mathrm{t}} \\
& \mathrm{P}_{\mathrm{t}}^{\mathrm{O}}=\mathrm{a}_{0}+\mathrm{a}_{1} \mathrm{P}_{\mathrm{t}-1}^{\mathrm{O}}+\mathrm{a}_{2} \mathrm{X}_{\mathrm{t}}+\mathrm{a}_{3} \mathrm{REV}_{\mathrm{t}}+\mathrm{a}_{4} \mathrm{DG}^{*} \mathrm{REV}_{\mathrm{t}}+\mathrm{e}_{\mathrm{t}}
\end{aligned}
$$

The dependent variable $(\mathrm{P})$ in both equations is the year-on-year change in the popularity rating of the government (indicated by superscript $G$ ) or opposition (superscript $\mathrm{O}$ ) as defined in section 4.1. ${ }^{13}$ We thus estimate the model in changes,

12 Data availability imposes this starting point. As mentioned, 1991 is removed from the sample. With data points lost due to the lagged dependent variable, we are left with 94 observations.

13 Alternatively, we define government (opposition) popularity as the share of people showing approval $(+1$ to +5$)$ minus the proportion expressing disapproval $(-1$ to -5$)$. This change in the dependent variable leaves our conclusions unaffected (full results available upon request). 
rather than levels. Both types of estimation have been used in the prior literature and it is not clear a priori which one is to be preferred on a theoretical basis. Here, however, estimation in changes is dictated by the structure of the data (i.e. the need to define yearon-year deviations to correct for strong seasonal effects in the economic and taxation data). As explanatory variables, our model first of all includes one lag of the dependent variable $\left(\mathrm{P}_{\mathrm{t}-1}\right)$. This picks up slow adjustment of popularity ratings and also tackles the problem of autocorrelation (which is present when this lag is left out). Slow adjustment of popularity is a common finding in the literature and indicates the weight of past events on voters' decision-making process (e.g. Frey and Schneider, 1978; Kernell, 1978; Geys and Vermeir, 2008).

Central to the analysis is a measure for the tax burden $\left(\mathrm{REV}_{t}\right)$. It is operationalised as the real year-on-year percentage change in total tax revenues (as depicted in Figure 2) or, alternatively, the real year-on-year percentage change in tax revenues from the four taxation types distinguished in Figure 3. As argued in Hypothesis 1, we expect a higher tax burden to lower the government's approval ratings; i.e. $b_{3}<0 .{ }^{14}$ Hypotheses $2 \mathrm{a}$ and $2 \mathrm{~b}$ indicate that this (expected) loss in government popularity is most likely to be complemented by a loss of support for the opposition when it has significant political power (that is, when it holds the majority position in the Bundesrat). Indeed, ratification of undesirable policies when it has the power to block or delay them may lead to popular retribution for the opposition. When the opposition is powerless, it is more likely to remain unaffected by (or even gain from) unpopular actions taken by the government. To capture this, we define an indicator variable (DG) equal to 1 in situations of 'divided government' ( 0 otherwise) and interact this with the tax burden variable. $^{15}$ Hypotheses $2 a$ and $2 b$ then predict that $\mathrm{a}_{3}>0$ and $\mathrm{a}_{4}<0$. Importantly, as voters might hold the government responsible only for taxation when it has a distinct influence on the tax burden (cfr. Hypothesis 3), significant coefficient estimates for the taxation variables are expected to be constrained to 'Gemeinschaftssteuern' and 'Bundessteuern'. Since the other two types of taxation (i.c. 'Landessteuern' and 'Gemeindesteuern') are imposed at lower levels of government, no effect of these revenues is expected at the federal level. ${ }^{16}$

Our vector of control variables, $\mathrm{X}_{\mathrm{t}}$, contains both economic and political controls. As economic variables, we include inflation (i.e. the year-on-year percentage change in the Consumer Price Index) and unemployment (i.e. the year-on-year deviation in the unemployment rate). Both are expected to depress the government's popularity and (potentially) increase that of the opposition. Note that we experimented with the yearon-year growth rate of real GDP. This, however, proved to be insignificant once unemployment is taken into account (although it consistently has the expected positive sign). Hence, given the strong relation between unemployment and real GDP growth ( $r$

14 This assumes that the government is on average taxing on the left side of the Laffer curve (such that increasing tax rates increase revenues). While this is not necessarily the case for all taxes (e.g. cigarette tax increases tend to decrease revenues, but are nonetheless unpopular), the assumption is reasonable when regarding overall tax policies. We thank Kai A. Konrad for this insight.

15 To accurately measure and interpret this interaction term, we also include the dummy for divided government as control variable in the estimations.

16 When the regional (or municipal) government has the same political constellation as the federal government, voters' disapproval with local taxation might, however, 'spill over' to the federal government (affecting the federal government's popularity in these particular states). Unfortunately, our data do not allow us to test this effect. 
$=-0.57$ ), we exclude this variable from the final model (results including GDP are available upon request, and similar to those presented).

As political variables, we first include two dummy variables for governments headed by Helmut Kohl (1 between 1982:4 and 1998:3, 0 otherwise) and Gerhard Schröder (1 between 1998:4 and 2003:4, 0 otherwise). The reference category is Chancellor Helmut Schmidt. These administration dummies pick up Chancellor-specific effects on government popularity ratings. Our second political variable assesses the existence of a 'honeymoon' effect (or 'popularity credit'). This relates to the period of goodwill that a government faces in the first quarters of its term (Mueller, 1970; Smyth and Dua, 1989; Goergen and Norpoth, 1991; Fox and Phillips, 2003). We measure this through a variable that is 4, 3, 2 and 1 in the second, third, fourth and fifth quarter of each administration respectively, and 0 in all other quarters (the first quarter of each government is dropped due to a lack of lagged dependent variable for those periods). The third political variable intends to capture 'pre-election rebounds' in politician's popularity (e.g. Frey and Schneider, 1978; Nannestad and Paldam, 1994; Schmitt and Wüst, 2006). Party leaders are very active in this period to present themselves from their best side to convince voters of their abilities (Goodhardt and Bhansali, 1970; Cusack, 1999). We model this effect as a dummy equal to 1 in the election year, 0 otherwise.

Finally, we add a set of dummy variables to control for various time-specific events. The fall of the Berlin Wall, for example, has been argued to have created a (temporary) surge in government popularity (Cusack, 1999). We capture this by a dummy variable equal to 1 in the period 1989:3-1990:1. More recently, a scandal over illegal CDU party donations - uncovered at the beginning of the millennium - is argued to have aided the popularity of the ruling SPD-Green government in the first quarters of 2000 (Schmitt and Wüst, 2006). This boost in government popularity was probably also supported by the government's promise in January 2000 to 'invest' $€ 125$ million to aid the bailout of Germany's biggest construction company (i.e. Philipp Holzmann A.G.), thereby saving up to 70.000 jobs. We capture the effect of these events through a dummy variable equal to 1 in the period 2000:1-2000:3. Preliminary analysis also indicated significant outliers in the popularity series for the quarters 1988:1, 1992:1, 1993:1, 1994:1, 1999:34; 2002:2 and 2002:4. Dummy variables for these quarters were included in all analyses to control for events causing a shock to popularity ratings in these periods (cfr. Feld and Kirchgässner, 2000). Summary statistics for all variables are presented in Appendix A.

\subsection{Results}

Before running the model, we test for non-stationarity through augmented DickeyFuller unit-root tests. Following a general-to-specific rule (cfr. Hall, 1994; Maddala and Kim, 2004), we start out with a large number of lags $\left(\mathrm{k}_{\max }\right)$ and remove these until the largest one is statistically significant at conventional levels. In line with Schwert (1989), we thereby set $k_{\max }$ equal to the integer part of $12 .(\mathrm{T} / 100)^{1 / 4}$, with $\mathrm{T}$ representing the number of observations. As $\mathrm{T}=94$ observations, $\mathrm{k}_{\max }=11$ lags. Note also that inclusion of a trend variable and constant term in the test procedure was based on statistical significance of these variables. This follows Guilkey and Schmidt (1991) and Elder and Kennedy (2001) who argue that including too many such 'deterministic' variables reduces the power of the test while incorrectly excluding them biases it in favour of the unit-root null hypothesis. The results of the unit root tests (presented in 
Table 1) indicate that all variables except inflation are stationary. As the first difference of this variable is stationary, we include inflation in first-differenced form (implying we introduce the change in the inflation rate).

\section{Table 1}

about here

Our main estimation results are given in Table 2. We provide three sets of results. Columns (1) and (4) show the basic results in which the taxation effect is estimated through total tax revenues. In Columns (2) and (5), we differentiate between the four tax sources distinguished in Figure 3. Finally, Columns (3) and (6) present results from a differentiation between expected and unexpected tax revenue changes (explained below).

Table 2

about here

Before discussing the central - fiscal - variables, we briefly summarize the main findings with respect to our control variables. Firstly, for both government and opposition, the lagged dependent variable indicates that 50 to 58 percent of the change in the popularity rating persists into the subsequent period, indicating slow adjustment of political popularity. Secondly, unemployment exerts a strong negative influence on government popularity, though it does not affect the popularity of the opposition. Inflation has a marginal (and unexpectedly positive) effect on both government and opposition popularity. The latter might indicate that the electorate understands that the Bundesbank - which was highly independent and committed to its inflation target (Schächter and Stokman, 1995; Lohmann, 1998; Cusack, 1999) - rather than the government was to be held responsible for inflation.

The political variables in the model mostly confirm earlier findings. First, the highly significant positive honeymoon effect shows that the public's endorsement of the government is higher in the first quarters of its term (cfr. Mueller, 1970). Unsurprisingly, no such honeymoon effect exists for the opposition. Second, there is a significant pre-election rebound for both government and opposition, though it is stronger for the former. Third, the fall of the Berlin wall boosted the German government's popularity. As the opposition failed to gain popularity from it, this breakthrough was apparently perceived as a success of the government only. Fourth, the insignificant effect of the divided government variable indicates that it plays little 
role whether or not the government controls both the Bundestag and Bundesrat (though, as noted below, divided versus unified government does influence the taxation effects; cfr. Lowry et al., 1998 for the US). The other time-specific effects included in the regression are individually and jointly highly significant, indicating the importance of including these variables to avoid misspecification. Finally, the administration dummies indicate that Chancellor-specific effects on German popularity ratings are at best rather weak (ceteris paribus).

Turning our attention to the tax variables, the results provide clear support for Hypothesis 1: there is a significant negative impact of taxation on government popularity (Column (1)). Specifically, a one standard deviation change in tax revenues (i.e. 4\%) alters the share of respondents that have a positive evaluation of their government with approximately $1.6 \%$. With respect to Hypothesis 2a, Column (4) shows that this loss of government popularity weakly benefits the opposition when this opposition has no control over the Bundesrat (i.e. in cases of 'unified government'). However, and in line with Hypothesis $2 b$, when the opposition does have a majority position in the Bundesrat, it appears to lose from an increasing tax burden (though the effect fails to reach statistical significance at the $5 \%$ level). Voters thus appear to understand the co-decision arrangement between Bundestag and Bundesrat and hold the opposition partly responsible for tax policies when it has control over the Bundesrat. ${ }^{17}$

Distinguishing between four tax revenue streams depending on the level of government that is responsible for them (see above) in Columns (2) and (5) suggests that not all taxes matter equally. In line with Hypothesis 3, the federal government is only punished for taxes that derive from federal tax legislation and accrue (at least in part) to the federal government. The effect of taxation at lower levels of government is statistically insignificant (and even positively signed). The opposition gains from higher 'Gemeinschaftssteuern' when it has no controlling stake in the Bundesrat, while the reverse holds under divided government (as expected under Hypotheses $2 \mathrm{a}$ and $2 \mathrm{~b}$ ). The remaining tax sources do not significantly affect the opposition. Still, as can be seen in Table B1 in Appendix B, this finding weakens when using Chancellor popularity or government/opposition vote shares as alternative independent variables. While Gemeinschaftssteuern always has the strongest effect (both qualitatively and statistically), none of the tax variables is statistically distinguishable from 0 (note, however, that the results regarding the total tax burden do hold up using these alternative dependent variables!).

Finally, as mentioned before, tax revenues are influenced by both the economy and tax policy. Hence, in Columns (3) and (6), we separate these effects using a two-stage estimation procedure proposed by Besley and Case (1995). Specifically, we first run an auxiliary regression in which we relate tax revenue changes to lagged tax revenue changes and current values for GDP growth. ${ }^{18}$ Then, the predicted values from this

17 An anonymous referee indicated that the costs of taxation may vary across governments of differing partisan leaning (cfr. Lowry et al., 1998; Sobel, 1998). To test this hypothesis, we included of a set of interaction terms (i.e. interacting the taxation variables with a dummy variable equal to 1 when SPD led the governing coalition; 0 when CDU did). The results show no significant differences in the cost of taxation for SPD and CDU-led governments over the period studied.

18 The results from this first stage regression are: $\Delta$ Taxrev $_{\mathrm{t}}=-0.003+0.552 \Delta \operatorname{Taxrev}_{\mathrm{t}-1}+0.005$ GDPgrowth $_{\mathrm{t}}$. The coefficient estimates for both the lag of tax revenue changes and GDP growth are statistically significant beyond the $99 \%$ confidence level. Note also that unemployment and inflation 
auxiliary regression (i.e. tax revenue changes which are 'expected' based on past changes and current economic events) and the residuals (i.e. 'unexpected' tax revenue changes, which tap into changes due to legislative actions) are added to the popularity function. Though this separation has theoretical merit, its empirical foundation is weaker. Firstly, it assumes voters' understanding of the impact of economic variables on fiscal outcomes and their ability to distinguish this from policy effects. This appears, at best, implausible (Besley and Case, 1995). Secondly, voters may simply want to punish unfavourable fiscal outcomes independent of their cause. Our findings provide some support for the latter point of view. Indeed, overall, the results show that the difference between the effects of 'expected' and 'unexpected' fiscal outcomes is at best statistically weak (as shown by the F-test at the bottom of Table 2, Columns (3) and (6)).

\section{Conclusion}

The literature on VP-functions shows that taxation often has an important effect on the popularity ratings and re-election odds of politicians. The present paper has provided a re-analysis of this taxation-popularity nexus using German data. Given the nearexclusive reliance in previous studies on US or UK data, such an extension to other countries is warranted to provide a more general view on the effect of taxation on popularity ratings (or election results).

The results allow us to formulate four conclusions. Firstly, taxation significantly reduces government popularity in Germany over the period 1978-2003. There thus is a clear disciplining reaction of voters towards governments that increase the tax burden. Secondly, this effect is not automatically translated into a more popular opposition. In fact, the opposition generally only gains (and then only insignificantly so) when it has no direct political power (i.e. when there is 'unified government'). When the government is 'divided' - i.e. the opposition is in control of the Bundesrat - the opposition tends to be punished for increased taxation. Thirdly, voters assign blame mainly for tax revenues that are under the direct influence of the federal government (i.e. Gemeinschafts- and Bundessteuern) and do not punish the government for a tax burden imposed by a lower level of government. Finally, no distinction is made by voters between tax revenue increases due to economic growth and those deriving from legislative changes. This may indicate bounded voter rationality in the sense that voters are probably unable to make a clear distinction between the various sources of tax burden increases - and therefore punish politicians equally for all increases.

Overall, it is clear that taxation matters. People dislike taxation and are willing (and capable) to show this resentment, leading to reduced popularity of politicians deemed responsible for a higher tax burden.

are insignificant when added and were therefore not retained. This indicates - in line with Koester (2006) - that the main economic determinant of tax revenues is economic growth. 


\section{References}

Anderson, C., 1995a. Party systems and the dynamics of government support: Britain and Germany 1960-1990. European Journal of Political Research 27, 93-118.

Anderson, C., 1995b. Blaming the Government: Citizens and the Economy in Five European Democracies. Armonk, M.E. Sharpe.

Anderson, C., 1996. Wirtschaftslage und Politischer Kontext: Kanzlerpopularität und Kanzlerparteipräferenz, 19850-1990. In: Gabriel, O.W., Falter, J.W., (Eds.), Wahlen und Politische Einstellungen in Westlichen Demokratien. Frankfurt, Peter Lang Verlag.

Ashworth, J., Heyndels, B., 2002. Tax structure turbulence in OECD countries. Public Choice, 111, 347-76.

Ashworth, J., Geys, B., Heyndels, B., 2006. Determinants of tax innovation: The case of environmental taxes in Flemish municipalities. European Journal of Political Economy 22 (1), 223-247.

Berry, F.S., 1988. Tax Policy Innovation in the American States. Ann Arbor, Michigan, UMI Dissertation Services.

Berry, F.S., Berry, W.D., 1992. Tax innovation in the States: Capitalizing on political opportunity. American Journal of Political Science 36 (3), 715-742.

Berry, F.S., Berry, W.D., 1994. The politics of tax increases in the States. American Journal of Political Science 38 (3), 855-859.

Besley, T., Case, A., 1995. Incumbent behavior: Vote-seeking, tax-setting and yardstick competition. American Economic Review 85, 25-45.

Brody, R., Sigelman, L., 1983. Presidential popularity and presidential elections: An update and an extension. Public Opinion Quarterly 47, 325-328.

Boix, C., 1998. Political Parties, Growth and Equality. Conservative and Social Democratic Economic Strategies in the World Economy. Cambridge, Cambridge University Press.

Cameron, D.R., 1978. The expansion of the public economy: A comparative analysis. American Political Science Review 72, 1243-1261.

Case, A., 1994. Taxes and the electoral cycle: How sensitive are governors to coming elections? Business Review, March/April, 17-26.

Chapell, H.W., 1990. Economic performance, voting and political support: A unified approach. Review of Economics and Statistics 72, 313-320.

Cusack, T.R., 1999. The shaping of popular satisfaction with government and regime performance in Germany. British Journal of Political Science 29, 641-672.

Cuzán, A.G., Bundrick, C.M., 1999. Fiscal policy as a forecasting factor in Presidential elections. American Politics Quarterly 27(3), 338-353.

Downs, A., 1957. An Economic Theory of Democracy. New York, Harper and Row.

Eismeier, T.J., 1979. Budgets and ballots: The political consequences of fiscal choice. In: Rae, D., Eismeier, T. (Eds.), Public Policy and Public Choice. Beverly Hills, Sage, pp. 121-149. 
Elder, J., Kennedy, P.E., 2001. Testing for unit roots: What should students be taught? Journal of Economic Education 31 (2), 137-146.

Feld, L.P., Kirchgässner, G., 2000. Official and hidden unemployment and the popularity of the government: An econometric analysis for the Kohl government. Public Choice 19, 333-347.

Feldman, S., Conley, P., 1991. Explaining Explanations of Changing Economic Conditions. In: Norpoth, H., Lewis-Beck, M., Lafay, J-D. (Eds.), Economics and Politics: The Calculus of Support. Ann Arbor, University of Michigan Press, pp. 185-206.

Fiorina, M.P., 1981. Retrospective Voting in American National Elections. New Haven, Yale University Press.

Fox, G., Phillips, E.N., 2003. Interrelationship between presidential approval, presidential votes and macroeconomic performance, 1948-2000. Journal of Macroeconomics, 25 411-424.

Frey, B., Schneider, F., 1978. An empirical study of politico-economic interaction in the United States. Review of Economics and Statistics 60, 174-183.

Frey, B., Schneider, F., 1981. Popularity functions: The case of the US and West Germany. In Whiteley, P. (Ed.), Models of Political Economy. London, Sage, pp. 4784.

Fuller, W.A., 1976. Introduction to Statistical Time-Series. New York, John Wiley and Sons.

Garrett, G., 1998. Partisan Politics in the Global Economy. Cambridge, Cambridge University Press.

Geys, B., Vermeir, J., 2008. Taxation and presidential approval: Separate effects from tax burden and tax structure turbulence? Public Choice forthcoming.

Gibson, J.G., 1994. Voter reaction to tax change: the case of the poll tax. Applied Economics 26, 877-884.

Goergen, C., Norpoth, H., 1991. Government turnover and economic accountability. Electoral Studies 10(3), 191-207.

Goodhardt, C.A.E., Bhansali, R.J., 1970. Political economy. Political Studies 18, 43106.

Gschwend, T., Norpoth, H., 2000. Soll und Haben: Die Deutsche Wählerschaft rechnet mit den Parteien ab. In: Klein, M., Jagodzinski, W., Mochmann, E., Ohr, D. (Eds.), Fünfzig Jahre Empirische Wahlforschung in Deutschland: Entwicklung, Befunde, Perspektiven, Daten. Opladen, Westdeutscher Verlag, pp. 389-409.

Guilkey, D.K., Schmidt, P., 1991. An interpolation test for a unit root in the presence of drift. Biometrika 78 (4), 809-815.

Hall, A., 1994. Testing for a unit root in time series with pretest data-based model selection. Journal of Business and Economic Statistics 12, 461-470.

Hansen, S.B., 1999. Life is not fair: Governors' job performance ratings and state economies. Political Research Quarterly 52, 167-188.

Happy, J.R., 1992. The effect of economic and fiscal performance on incumbency voting: The Canadian case. British Journal of Political Science 22, 117-130. 
Hibbs, D.A., Jr., 2000. Bread and peace voting in U.S. presidential elections. Public Choice 104, 149-180.

Hibbs, D.A., Jr., Madsen, H.J., 1981. The impact of economic performance on electoral support in Sweden, 1967-1978. Scandinavian Political Studies 4, 33-50.

Hossain, F., 2007a. Where the Republicans stand. International Herald Tribune 31/12/2007, 4 .

Hossain, F., 2007b. Where the Democrats stand. International Herald Tribune $31 / 12 / 2007,5$.

Jacobsen, G.C., 1983. The Politics of Congressional Elections. Boston, Little, Brown \& Co.

Johnson, P., Lynch, F., Walker, J.G., 2005. Income taxes and elections in Britain, 19502001. Electoral Studies 24 (3), 393-408.

Kelleher, C.A., Wolak, J., (2007). Explaining public confidence in the branches of state government. Political Research Quarterly forthcoming.

Kellerman, C., Rattinger, H., 2006. Economic conditions, unemployment and perceived government accountability. German Politics 15(4), 460-480.

Kernell, S., 1978. Explaining presidential popularity. American Political Science Review 72, 506-522.

Key Jr., V.O., 1966. The Responsible Electorate: Rationality in Presidential Voting, 1936-1960. Cambridge, Harvard University Press.

Kinder, D.R., Kiewiet, D.R., 1979. Economic discontent and political behavior: The role of personal grievances and collective economic judgments in congressional voting. American Journal of Political Science 23, 495-527.

Kirchgässner, G., 1976. Rationales Wählerverhalten und optimales Regierungsverhalten. Dissertation. Universität Konstanz.

Kirchgässner, G., 1977. Wirtschaftslage und Wählerverhalten: Eine empirische Studie für die Bundesrepublik Deutschland von 1971-1976. Politische Vierteljahresschrift $18,510-536$.

Kirchgässner, G., 1985a. Rationality, causality and the relation between economic conditions and the popularity of parties. European Economic Review 28, 243-268.

Kirchgässner, G., 1985b. Causality testing of the popularity function: An empirical investigation for the Federal Republic of Germany 1971-1982. Public Choice 45, 155-173.

Kirchgässner, G., 1986. Economic conditions and the popularity of West-German parties: A survey. European Journal of Political Research 14, 421-439.

Koester, G., 2006. Political motivation, tax policy and the development of tax structures: Evidence from the German case. Mimeo.

Kone, S.L., Winters, R.F., 1993. Taxes and voting: Electoral retribution in the American states. Journal of Politics 55, 22-40.

Landon, S., Ryan, D.L., 1997. The political costs of taxes and government spending. Canadian Journal of Economics 30, 85-111. 
Lanoue, D.J., 1994. Retrospective and prospective voting in presidential-year elections. Political Research Quarterly 47(1), 193-205.

Lewis-Beck, M.S., 1988. Economics and Elections: The Major Western Democracies. Ann Arbor, Michigan University Press.

Lewis-Beck, M.S., Paldam, M., 2000. Economic voting: An introduction. Electoral Studies 19, 113-121.

Lohmann, S., 1998. Federalism and central bank independence: The politics of German monetary policy, 1957-1992. World Politics 50, 401-446.

Lowry, R.C., Alt, J.E., Ferree, K.E., 1998. Fiscal policy outcomes and electoral accountability in American states. American Political Science Review 92, 759-774.

MacDonald, J.A., Sigelman, L., 1999. Public assessments of gubernatorial performance. A comparative state analysis. American Politics Quarterly 27, 201-215.

Maddala, G.S., Kim, I.M., 2004. Unit Roots, Cointegration and Structural Change. Cambridge, Cambridge University Press.

Maier, J., Rattinger, H., 1999. Economic conditions and the 1994 and 1998 federal elections. German Politics 8(2), 33-47.

Maier, J., Rattinger, H., 2004. Economic conditions and voting behaviour in German federal elections 1994-2002. German Politics 13(2), 201-217.

Mikesell, J.L., 1978. Election periods and state tax policy cycles. Public Choice 33, 99105.

Miller, W.L., Mackie, M. 1973. The electoral cycle and the asymmetry of government and opposition popularity: An alternative model of the relationship between economic conditions and popularity. Political Studies 21, 263-279.

Mueller, J., 1970. Presidential popularity from Truman to Johnson. American Political Science Review 64, 18-34.

Nannestad, P., Paldam, M., 1994. The VP-function: A survey of the literature on vote and popularity functions after 25 years. Public Choice 79, 213-245.

Niemi, R.G., Stanley, H.W., Vogel, R.J., 1995. State economies and state taxes: Do voters hold governors accountable? American Journal of Political Science 39, 936957.

Niskanen, W.A., 1975. Bureaucrats and politicians. Journal of Law and Economics 18, 617-643.

Niskanen, W.A., 1979. Economic and fiscal effects on the popular vote for the president. In: Rae, D., Eismeier, T. (Eds.), Public Policy and Public Choice. Beverly Hills, Sage, pp. 93-120.

Norpoth, H., Goergen, C., 1990. Regierungspopularität auf Kredit: Wirtschaftsbilanz, Wende und Wählerwille. In: Kaase, M., Klingemenn, H.-D. (Eds.), Wahlen und Wähler: Analysen aus Anlass der Bundestagswahl 1987. Opladen, Westdeutscher Verlag.

Norpoth, H., Gschwend, T., 2003. The Red-Green victory: Against all odds? German Politics and Society 21, 15-34. 
Norpoth, H., Yantek, T., 1983. Von Adenauer bis Schmidt: Wirtschaftslage und Kanzlerpopularität. In: Kaase, M., Klingemenn, H.-D. (Eds.), Wahlen und Politisches System. Opladen, Westdeutscher Verlag.

Paldam, M., 1991. How robust in the vote function?: A study of seventeen nations over four decades. In: Norpoth, H., Lewis-Beck, M., Lafay, J-D. (Eds.), Economics and Politics: The Calculus of Support. Ann Arbor, University of Michigan Press, pp. 931 .

Paldam, M., Schneider, F., 1980. The macro-economic aspects of government and opposition popularity in Denmark 1957-78. Nationalokonomisk Tidsskrift 2, 149170.

Peltzman, S., 1992. Voters as fiscal conservatives. Quarterly Journal of Economics 107, 327-361.

Pissarides, C.A., 1980. British government popularity and economic performance. The Economic Journal 90, 569-581.

Pomper, G.M., 1968. Elections in America: Control and Influence in American Politics. New York, Dodd, Mead \& Company.

Ramsey, J.B., 1969. Tests for specification error in classical least squares regression analysis. Journal of the Royal Statistical Society B31, 250-271.

Rattinger, H. (1979). Auswirkungen der Arbeitsmarktklage auf das Ergebnis der Bundestagwahl 1976. Politische Vierteljahresschrift 20(1), 51-70.

Rattinger, H., 1986. Collective and individual economic judgments and voting in West Germany 1961-1984. European Journal of Political Research 14, 393-419.

Rattinger, H., 2000. Konjunkturentwicklung, Wahrnehmungen der Wirtschaftslage und Parteipräferenzen in Deutschland, 1977-1998. In: Klein, M., Jagodzinski, W., Mochmann, E., Ohr, D. (Eds.), Fünfzig Jahre Empirische Wahlforschung in Deutschland: Entwicklung, Befunde, Perspektiven, Daten. Opladen, Westdeutscher Verlag, pp. 309-339.

Rogoff, K., Sibert, A., 1988. Elections and macroeconomic policy cycles. Review of Economic Studies 55, 1-16.

Schächter A., Stokman, A.C.J., 1995. Interest rate policy of the deutsche Bundesbank: An econometric analysis for 1975 to 1992. De Economist 143 (4), 475-494.

Schimek, M., 1986. Empirische Legitimierungsmodelle für die Periode 1970-1981 der Sozialliberalen Regierung in der Bundesrepublik Deutschland. In: Kaase, M., Klingemenn, H.-D. (Eds.), Wahlen und Politischer Prozess. Opladen, Westdeutscher Verlag.

Schmitt, H., Wüst, A., 2006. The extraordinary Bundestag election of 2005: The interplay of long-term trends and short-term factors. German Politics and Society 24 (1), 27-46.

Schwert, G.W., 1989. Test for unit roots: A Monte Carlo investigation. Journal of Business and Economics Statistics 7, 147-159.

Sigelman, L., 1979. Presidential popularity and presidential elections. Public Opinion Quarterly 43, 532-534. 
Smyth, D.J., Dua, P., 1989. The public's indifference map between inflation and unemployment: Empirical evidence for the Nixon, Ford, Carter and Reagan presidencies. Public Choice 60, 71-85.

Sobel, R.S., 1998. The political costs of tax increases and expenditure reductions: Evidence from state legislative turnover. Public Choice 96, 61-79.

Stults, B.G., Winters, R.F., 2005. The political economy of taxes and the vote. Mimeo.

Turett, S., 1971. The vulnerability of American governors, 1900-1969. Midwest Journal of Political Science 15, 108-132.

Veiga, F.J., Veiga, L.G., 2004. The determinants of vote intentions in Portugal. Public Choice 118(3-4), 341-364.

Vermeir, J., 2006. Essays on Elections and Coalition Formation. Unpublished Doctoral Dissertation, Vrije Universiteit Brussel, Brussels. 
Appendix A: Summary statistics

Table A1: Summary Statistics ( $N=94)$

\begin{tabular}{|c|c|c|c|c|}
\hline Variable & Mean & $\begin{array}{l}\text { Standard } \\
\text { deviation }\end{array}$ & Minimum & Maximum \\
\hline $\begin{array}{l}\text { Government Approval } \\
\text { (year-on-year change) }\end{array}$ & -1.239 & 11.67 & -24.63 & 25.40 \\
\hline $\begin{array}{l}\text { Opposition Approval } \\
\text { (year-on-year change) }\end{array}$ & -0.209 & 7.76 & -24.50 & 16.83 \\
\hline GDP Growth & 1.725 & 2.26 & -2.76 & 7.35 \\
\hline Inflation & 2.516 & 1.78 & -0.95 & 7.13 \\
\hline $\begin{array}{c}\text { Unemployment } \\
\text { (year-on year change) }\end{array}$ & 0.049 & 0.14 & -0.15 & 0.53 \\
\hline $\begin{array}{c}\text { Tax Revenues } \\
\text { (year-on-year change) }\end{array}$ & 0.014 & 0.04 & -0.08 & 0.14 \\
\hline $\begin{array}{l}\text { Gemeinschaftssteuern } \\
\text { (year-on-year change) }\end{array}$ & 0.014 & 0.04 & -0.11 & 0.10 \\
\hline $\begin{array}{c}\text { Bundessteuern } \\
\text { (year-on-year change) }\end{array}$ & 0.024 & 0.11 & -0.29 & 0.52 \\
\hline $\begin{array}{c}\text { Laendessteuern } \\
\text { (year-on-year change) }\end{array}$ & 0.010 & 0.07 & -0.17 & 0.21 \\
\hline $\begin{array}{l}\text { Gemeindesteuern } \\
\text { (year-on-year change) }\end{array}$ & 0.004 & 0.07 & -0.26 & 0.21 \\
\hline Divided Government & 0.649 & 0.48 & 0 & 1 \\
\hline Honeymoon & 0.213 & 0.77 & 0 & 4 \\
\hline Election year & 0.277 & 0.45 & 0 & 1 \\
\hline Wall down & 0.032 & 0.18 & 0 & 1 \\
\hline
\end{tabular}


Appendix B: Results using alternative independent variables

Table B1: Determinants of German government and opposition approval ratings 1978-2003

\begin{tabular}{|c|c|c|c|c|c|c|}
\hline & $\begin{array}{c}\text { Vote share } \\
\text { Governing } \\
\text { parties }\end{array}$ & $\begin{array}{c}\text { Vote share } \\
\text { Governing } \\
\text { parties }\end{array}$ & $\begin{array}{c}\text { Vote share } \\
\text { Opposition } \\
\text { parties }\end{array}$ & $\begin{array}{c}\text { Vote share } \\
\text { Opposition } \\
\text { parties }\end{array}$ & $\begin{array}{l}\text { Popularity } \\
\text { Chancellor }\end{array}$ & $\begin{array}{l}\text { Popularity } \\
\text { Chancellor }\end{array}$ \\
\hline Intercept & $\begin{array}{c}-3.390 * \\
(-1.71)\end{array}$ & $\begin{array}{c}-3.437 * \\
(-1.64)\end{array}$ & $\begin{array}{l}0.969 \\
(0.38)\end{array}$ & $\begin{array}{l}0.770 \\
(0.32)\end{array}$ & $\begin{array}{l}-2.343 \\
(-1.06)\end{array}$ & $\begin{array}{l}-2.820 \\
(-1.22)\end{array}$ \\
\hline $\begin{array}{l}\text { Approval (t-1) } \\
\text { (year-on-year change) }\end{array}$ & $\begin{array}{c}0.452 * * * \\
(5.74)\end{array}$ & $\begin{array}{c}0.415 * * * \\
(4.55)\end{array}$ & $\begin{array}{c}0.422 * * * \\
(4.34)\end{array}$ & $\begin{array}{c}0.384 * * * \\
(3.84)\end{array}$ & $\begin{array}{c}0.738 * * * \\
(13.03)\end{array}$ & $\begin{array}{c}0.744 * * * \\
(12.21)\end{array}$ \\
\hline $\begin{array}{l}\text { Unemployment rate } \\
\text { (year-on-year change) }\end{array}$ & $\begin{array}{c}-11.472 * * \\
(-2.31)\end{array}$ & $\begin{array}{c}-12.211 * * \\
(-2.55)\end{array}$ & $\begin{array}{l}2.860 \\
(0.54) \\
\end{array}$ & $\begin{array}{l}4.967 \\
(0.98) \\
\end{array}$ & $\begin{array}{c}-9.932 * \\
(-1.77) \\
\end{array}$ & $\begin{array}{c}-9.553 * \\
(-1.64) \\
\end{array}$ \\
\hline $\begin{array}{l}\text { Inflation rate } \\
\text { (first difference) }\end{array}$ & $\begin{array}{l}1.378 \\
(1.23)\end{array}$ & $\begin{array}{l}1.430 \\
(1.21)\end{array}$ & $\begin{array}{l}-1.142 \\
(-0.91) \\
\end{array}$ & $\begin{array}{l}-1.039 \\
(-0.85)\end{array}$ & $\begin{array}{c}2.622 * * \\
(2.09)\end{array}$ & $\begin{array}{c}2.961 * * \\
(2.25)\end{array}$ \\
\hline $\begin{array}{l}\text { Tax Revenues } \\
\text { (year-on-year change) }\end{array}$ & $\begin{array}{c}-34.919 * \\
(-1.95) \\
\end{array}$ & - & $\begin{array}{l}20.640 \\
(0.59) \\
\end{array}$ & - & $\begin{array}{c}-38.783 * \\
(-1.94) \\
\end{array}$ & - \\
\hline $\begin{array}{l}\text { Tax revenues * } \\
\text { Divided Government }\end{array}$ & - & - & $\begin{array}{l}-44.173 \\
(-1.05) \\
\end{array}$ & - & - & - \\
\hline $\begin{array}{l}\text { Gemeinschaftssteuern } \\
\text { (year-on-year change) }\end{array}$ & - & $\begin{array}{c}-20.243 \\
(-1.19)\end{array}$ & - & $\begin{array}{l}44.191 \\
(1.35)\end{array}$ & - & $\begin{array}{c}-25.714 * \\
(-1.73)\end{array}$ \\
\hline $\begin{array}{l}\text { Bundessteuern } \\
\text { (year-on-year change) }\end{array}$ & - & $\begin{array}{l}0.855 \\
(0.14)\end{array}$ & - & $\begin{array}{l}-29.001 \\
(-1.02)\end{array}$ & - & $\begin{array}{l}-9.609 \\
(-1.38)\end{array}$ \\
\hline $\begin{array}{l}\text { Laendessteuern } \\
\text { (year-on-year change) }\end{array}$ & - & $\begin{array}{l}-3.493 \\
(-0.45) \\
\end{array}$ & - & $\begin{array}{l}-4.863 \\
(-0.38) \\
\end{array}$ & - & $\begin{array}{l}8.482 \\
(1.00)\end{array}$ \\
\hline $\begin{array}{l}\text { Gemeindesteuern } \\
\text { (year-on-year change) }\end{array}$ & - & $\begin{array}{l}-10.171 \\
(-1.05) \\
\end{array}$ & - & $\begin{array}{l}-17.236 \\
(-0.95) \\
\end{array}$ & - & $\begin{array}{l}-8.764 \\
(-0.87) \\
\end{array}$ \\
\hline $\begin{array}{l}\text { Gemeinschaftssteuern* } \\
\text { Divided Government }\end{array}$ & & - & - & $\begin{array}{l}-46.426 \\
(-1.19)\end{array}$ & - & - \\
\hline $\begin{array}{l}\text { Bundessteuern* } \\
\text { Divided Government }\end{array}$ & - & - & - & $\begin{array}{l}5.839 \\
(0.20) \\
\end{array}$ & - & - \\
\hline $\begin{array}{l}\text { Laendessteuern * } \\
\text { Divided Government }\end{array}$ & - & - & - & $\begin{array}{l}0.015 \\
(0.00) \\
\end{array}$ & - & - \\
\hline $\begin{array}{l}\text { Gemeindesteuern * } \\
\text { Divided Government }\end{array}$ & - & - & - & $\begin{array}{l}28.199 \\
(1.41)\end{array}$ & - & - \\
\hline Divided Government & $\begin{array}{l}0.980 \\
(0.76) \\
\end{array}$ & $\begin{array}{l}0.744 \\
(0.57) \\
\end{array}$ & $\begin{array}{l}0.157 \\
(0.09)\end{array}$ & $\begin{array}{l}0.052 \\
(0.03) \\
\end{array}$ & $\begin{array}{l}0.167 \\
(0.11) \\
\end{array}$ & $\begin{array}{l}0.432 \\
(0.29) \\
\end{array}$ \\
\hline Honeymoon & $\begin{array}{c}3.792 * * * \\
(4.75)\end{array}$ & $\begin{array}{c}3.889 * * * \\
(4.67)\end{array}$ & $\begin{array}{l}-1.491 * \\
(-1.83) \\
\end{array}$ & $\begin{array}{c}-1.984 * * \\
(-2.59) \\
\end{array}$ & $\begin{array}{c}3.101 * * * \\
(3.63)\end{array}$ & $\begin{array}{c}3.043 * * * \\
(3.48)\end{array}$ \\
\hline Election year & $\begin{array}{c}4.033 * * * \\
(3.27)\end{array}$ & $\begin{array}{c}4.154 * * * \\
(3.21)\end{array}$ & $\begin{array}{l}-1.508 \\
(-1.07)\end{array}$ & $\begin{array}{l}-1.172 \\
(-0.81) \\
\end{array}$ & $\begin{array}{c}5.380 * * * \\
(3.84)\end{array}$ & $\begin{array}{c}5.278 * * * \\
(3.62)\end{array}$ \\
\hline Wall down & $\begin{array}{c}5.229^{* *} \\
(1.96) \\
\end{array}$ & $\begin{array}{c}5.942 * * \\
(2.06) \\
\end{array}$ & $\begin{array}{l}-3.413 \\
(-1.17) \\
\end{array}$ & $\begin{array}{l}-0.886 \\
(-0.26) \\
\end{array}$ & $\begin{array}{l}3.313 \\
(1.11) \\
\end{array}$ & $\begin{array}{l}3.678 \\
(1.14) \\
\end{array}$ \\
\hline F (Event dummies) & $4.82 * * *$ & $4.15 * * *$ & $3.64 * * *$ & $4.87 * * *$ & $14.20 * * *$ & $13.03 * * *$ \\
\hline F (Administrations) & 1.87 & 1.87 & 0.24 & 0.67 & 0.90 & 1.12 \\
\hline $\mathrm{R}^{2}$ adj & 68.43 & 68.69 & 52.67 & 53.19 & 84.92 & 85.36 \\
\hline Breusch-Godfrey & $5.85 * *$ & $7.15^{* * *}$ & 0.21 & 0.97 & 1.06 & 0.82 \\
\hline Heteroscedasticity & 0.14 & 0.09 & 3.18 & $7.54 * * *$ & 0.39 & 0.07 \\
\hline RESET $^{3}$ & 1.31 & 1.39 & 1.71 & 1.59 & 1.28 & 1.78 \\
\hline
\end{tabular}

Note: $\mathrm{N}=94$. t-values between brackets. ${ }^{* * *}$ significant at $1 \% ; * *$ at $5 \%$ and $*$ at $10 \% . \quad \mathrm{F}$ (Event dummies) and F(Administrations) test joint significance of time-specific and administration-specific effects, BreuschGodfrey and Heteroscedasticity assess autocorrelation and heteroscedasticity respectively. RESET3 is Ramsey's (1969) specification error test. 
Figure 1: Popularity of German government and opposition: 1977:1-2003:4 (\%)

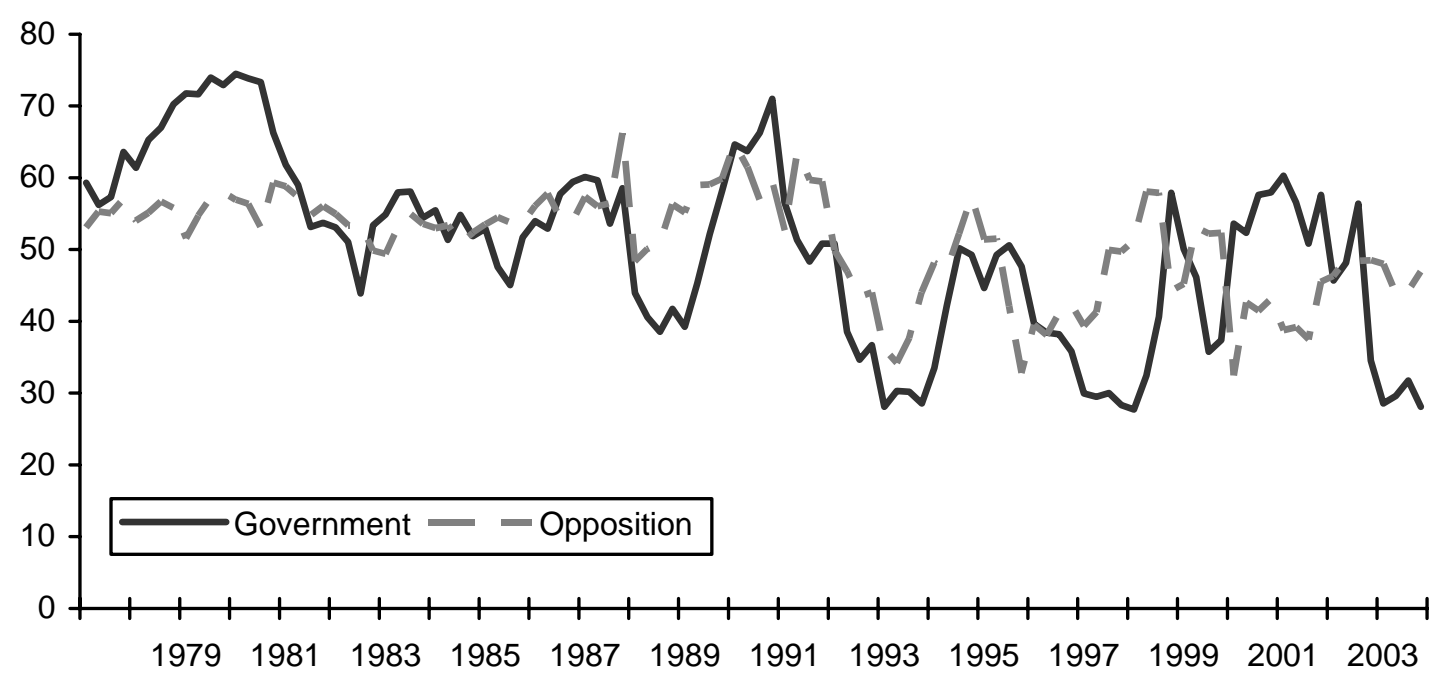

Figure 2: Year-on-year change in real total tax revenues: 1977:1-2003:4 (\%)

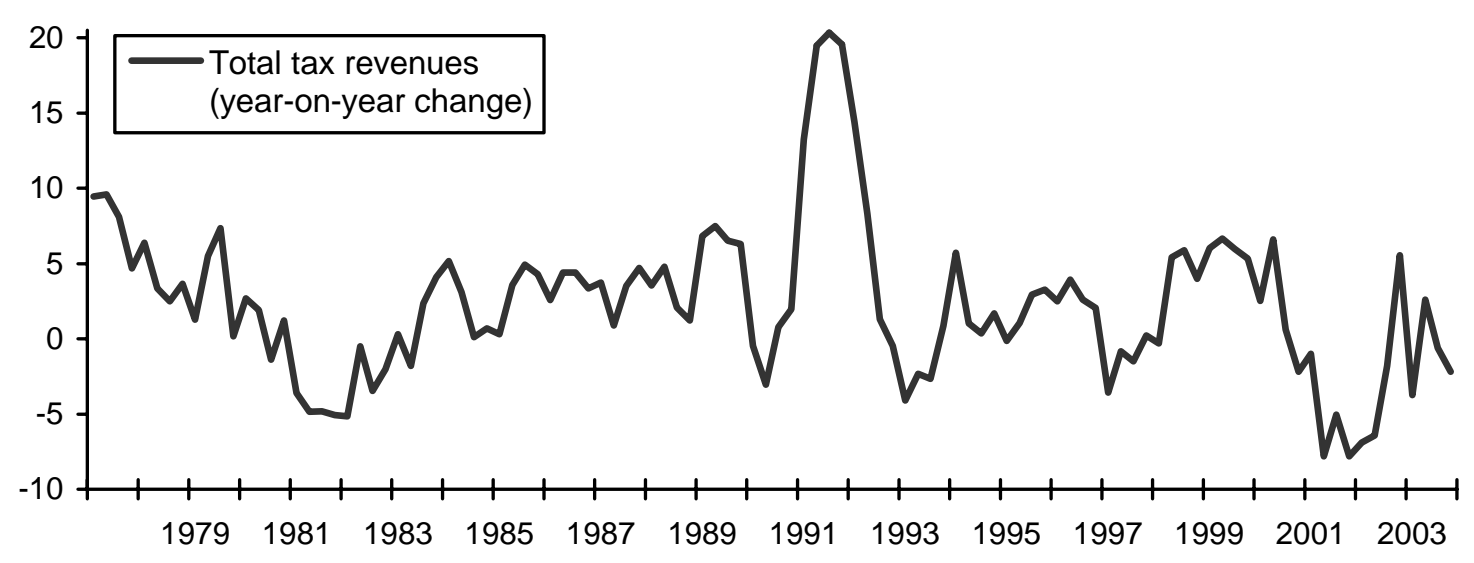

Figure 3: Year-on-year change in real total tax revenues at different government levels: 1977:1-2003:4 (\%)

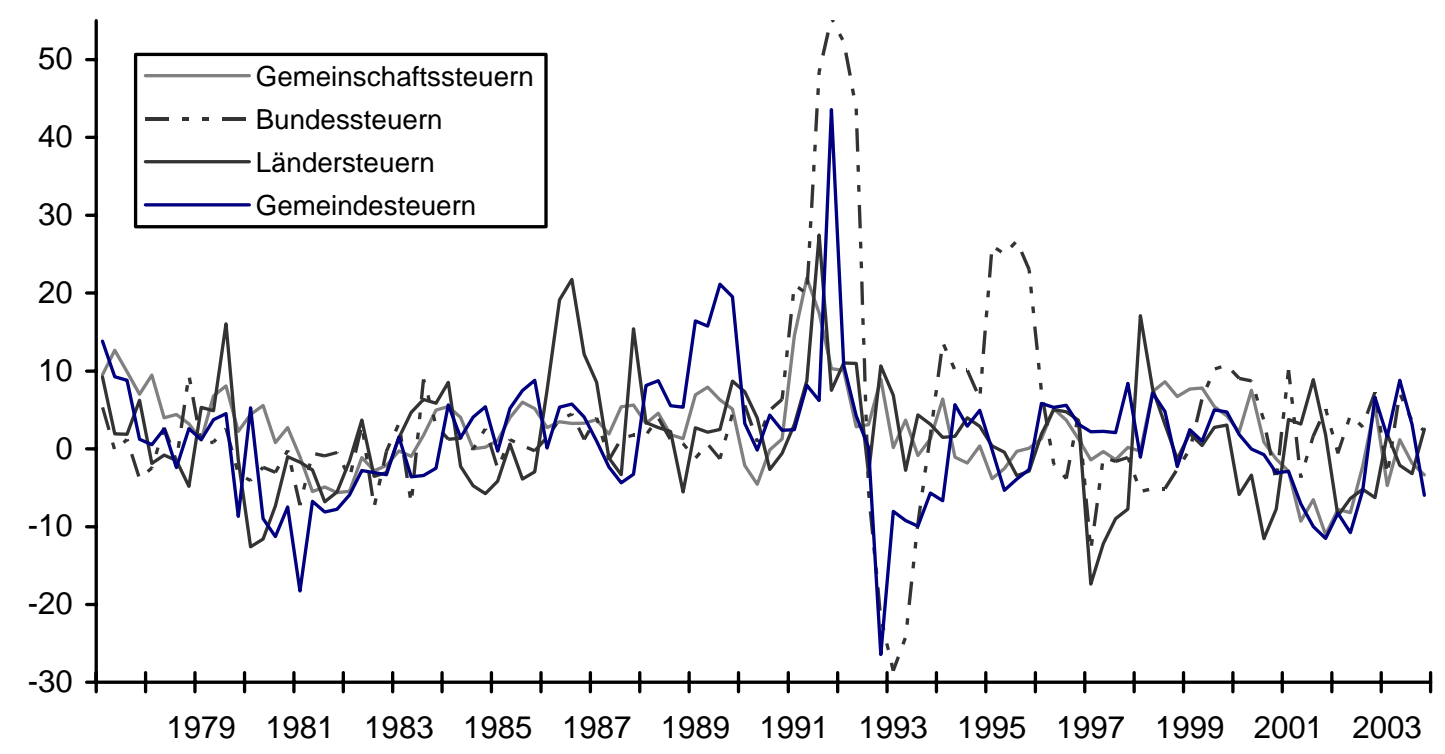


Table 1: Results from Augmented Dickey-Fuller unit-root tests

\begin{tabular}{|l|l|l|l|}
\hline Variable & \# lags & $\boldsymbol{\tau}_{\boldsymbol{\mu}}$ & Inference \\
\hline Government Approval $^{\mathrm{b}}$ & 9 & $-4.51^{* * *}$ & Stationary \\
\hline Opposition Approval $^{\mathrm{b}}$ & 9 & $-3.97 * * *$ & Stationary \\
\hline Tax Revenues $^{\mathrm{c}}$ & 4 & $-3.69 * * *$ & Stationary \\
\hline Gemeinschaftssteuern $^{\mathrm{b}}$ & 4 & $-2.95 * * *$ & Stationary \\
\hline Bundessteuern $^{\mathrm{b}}$ & 10 & $-1.98 * *$ & Stationary \\
\hline Landessteuern $^{\mathrm{b}}$ & 8 & $-2.22 * *$ & Stationary \\
\hline Gemeindesteuern $^{\mathrm{b}}$ & 11 & $-2.46 * *$ & Stationary \\
\hline Unemployment $^{\mathrm{b}}$ & 1 & $-3.22 * * *$ & Stationary \\
\hline Real GDP growth $^{\mathrm{c}}$ & 3 & $-3.28 * * *$ & Stationary \\
\hline Inflation $^{\mathrm{a}}$ & 9 & -2.70 & Unit root \\
\hline Inflation, first differences $^{\mathrm{b}}$ & 11 & $-3.63^{* * *}$ & Stationary \\
\hline
\end{tabular}

Note: Critical values $\tau_{\mu}$, are in Fuller (1976). Inclusion of a drift parameter (or constant term) and time trend were based on statistical significance of these variables. Superscript ${ }^{\text {a }}$ refers to inclusion of both constant and time trend, superscript ${ }^{b}$ indicates the absence of both while superscript ${ }^{\mathrm{c}}$ implies inclusion of a constant term only. 
Table 2: Determinants of German government and opposition approval ratings 1978-2003

\begin{tabular}{|c|c|c|c|c|c|c|}
\hline & $\begin{array}{c}\text { (1) } \\
\text { GOV }\end{array}$ & $\begin{array}{c}(2) \\
\text { GOV }\end{array}$ & $\begin{array}{c}\text { (3) } \\
\text { GOV }\end{array}$ & $\begin{array}{c}\text { (4) } \\
\text { OPP }\end{array}$ & $\begin{array}{l}\text { (5) } \\
\text { OPP }\end{array}$ & $\begin{array}{l}\text { (6) } \\
\text { OPP }\end{array}$ \\
\hline Intercept & $\begin{array}{c}-4.063 * \\
(-1.84)\end{array}$ & $\begin{array}{l}-3.595 \\
(-1.58)\end{array}$ & $\begin{array}{c}-4.212 * \\
(-1.81) \\
\end{array}$ & $\begin{array}{l}-4.576 \\
(-1.54)\end{array}$ & $\begin{array}{l}-3.283 \\
(-1.11)\end{array}$ & $\begin{array}{l}-2.041 \\
(-0.61)\end{array}$ \\
\hline $\begin{array}{l}\text { Approval }(\mathrm{t}-1) \\
\text { (year-on-year change) }\end{array}$ & $\begin{array}{c}0.561 * * * \\
(9.43)\end{array}$ & $\begin{array}{c}0.576 * * * \\
(8.65)\end{array}$ & $\begin{array}{c}0.561 * * * \\
(9.37)\end{array}$ & $\begin{array}{c}0.523 * * * \\
(5.65)\end{array}$ & $\begin{array}{c}0.508 * * * \\
(5.28)\end{array}$ & $\begin{array}{l}0.527 * * * \\
(5.79)\end{array}$ \\
\hline $\begin{array}{l}\text { Unemployment rate } \\
\text { (year-on-year change) }\end{array}$ & $\begin{array}{c}-17.065 * * * \\
(-2.81)\end{array}$ & $\begin{array}{c}-17.455 * * \\
(-2.72)\end{array}$ & $\begin{array}{c}-16.536 * * \\
(-2.50)\end{array}$ & $\begin{array}{l}-3.080 \\
(-0.52)\end{array}$ & $\begin{array}{l}-5.215 \\
(-0.87)\end{array}$ & $\begin{array}{l}-8.827 \\
(-1.38)\end{array}$ \\
\hline $\begin{array}{l}\text { Inflation rate } \\
\text { (first difference) }\end{array}$ & $\begin{array}{c}2.223 * \\
(1.78)\end{array}$ & $\begin{array}{l}2.079 \\
(1.62) \\
\end{array}$ & $\begin{array}{c}2.254^{*} \\
(1.78) \\
\end{array}$ & $\begin{array}{l}2.350 \\
(1.60)\end{array}$ & $\begin{array}{l}2.175 \\
(1.46)\end{array}$ & $\begin{array}{l}1.904 \\
(1.31)\end{array}$ \\
\hline $\begin{array}{l}\text { Tax Revenues } \\
\text { (year-on-year change) }\end{array}$ & $\begin{array}{c}-40.234 * * \\
(-2.00)\end{array}$ & - & - & $\begin{array}{l}65.197 \\
(1.60) \\
\end{array}$ & - & - \\
\hline $\begin{array}{l}\text { Tax revenues * Divided } \\
\text { Government }\end{array}$ & - & - & - & $\begin{array}{c}-101.873 * * \\
(-2.05)\end{array}$ & - & - \\
\hline Unexpected Tax Revenue Change & - & - & $\begin{array}{c}-42.230 * \\
(-1.88)\end{array}$ & - & - & $\begin{array}{c}89.566 * \\
(1.92)\end{array}$ \\
\hline Expected tax revenue change & - & - & $\begin{array}{c}-35.428 \\
(-1.15) \\
\end{array}$ & - & - & $\begin{array}{c}-14.614 \\
(-0.20) \\
\end{array}$ \\
\hline $\begin{array}{l}\text { Unexpected tax revenue change* } \\
\text { Divided Government }\end{array}$ & - & - & - & - & - & $\begin{array}{c}-99.425 * \\
(-1.77)\end{array}$ \\
\hline $\begin{array}{l}\text { Expected Tax Revenue Change* } \\
\text { Divided Government }\end{array}$ & - & - & - & - & - & $\begin{array}{c}-74.277 \\
(-0.91)\end{array}$ \\
\hline $\begin{array}{l}\text { Gemeinschaftssteuern } \\
\text { (year-on-year change) }\end{array}$ & - & $\begin{array}{c}-46.299 * * \\
(-2.49)\end{array}$ & - & - & $\begin{array}{c}80.033 * \\
(1.94)\end{array}$ & - \\
\hline $\begin{array}{l}\text { Bundessteuern } \\
\text { (year-on-year change) }\end{array}$ & - & $\begin{array}{c}-12.721 * \\
(-1.84)\end{array}$ & - & - & $\begin{array}{l}-42.314 \\
(-1.19)\end{array}$ & - \\
\hline $\begin{array}{l}\text { Laendessteuern } \\
\text { (year-on-year change) }\end{array}$ & - & $\begin{array}{c}13.194 \\
(1.58) \\
\end{array}$ & - & - & $\begin{array}{l}8.410 \\
(0.54) \\
\end{array}$ & - \\
\hline $\begin{array}{l}\text { Gemeindesteuern } \\
\text { (year-on-year change) }\end{array}$ & - & $\begin{array}{l}6.450 \\
(0.64)\end{array}$ & - & - & $\begin{array}{c}-21.626 \\
(-1.01)\end{array}$ & - \\
\hline $\begin{array}{l}\text { Gemeinschaftssteuern } * \\
\text { Divided Government }\end{array}$ & - & - & - & - & $\begin{array}{c}-131.396 * * \\
(-2.63)\end{array}$ & - \\
\hline $\begin{array}{l}\text { Bundessteuern * } \\
\text { Divided Government }\end{array}$ & - & - & - & - & $\begin{array}{c}20.533 \\
(0.56)\end{array}$ & - \\
\hline $\begin{array}{l}\text { Laendessteuern * } \\
\text { Divided Government }\end{array}$ & - & - & - & - & $\begin{array}{l}10.016 \\
(0.52)\end{array}$ & - \\
\hline $\begin{array}{l}\text { Gemeindesteuern * } \\
\text { Divided Government }\end{array}$ & - & - & - & - & $\begin{array}{l}41.375 \\
(1.66)\end{array}$ & - \\
\hline Divided Government & $\begin{array}{l}0.900 \\
(0.62)\end{array}$ & $\begin{array}{l}1.618 \\
(1.10)\end{array}$ & $\begin{array}{l}0.945 \\
(0.64)\end{array}$ & $\begin{array}{l}2.329 \\
(1.06)\end{array}$ & $\begin{array}{l}2.727 \\
(1.25)\end{array}$ & $\begin{array}{l}1.007 \\
(0.36)\end{array}$ \\
\hline Honeymoon & $\begin{array}{c}3.067 * * * \\
(3.33)\end{array}$ & $\begin{array}{l}3.152 * * * \\
(3.32)\end{array}$ & $\begin{array}{c}3.069 * * * \\
(3.31)\end{array}$ & $\begin{array}{l}0.544 \\
(0.57)\end{array}$ & $\begin{array}{l}0.445 \\
(0.47)\end{array}$ & $\begin{array}{l}0.264 \\
(0.25)\end{array}$ \\
\hline Election year & $\begin{array}{c}6.646 * * * \\
(4.66)\end{array}$ & $\begin{array}{l}5.954 * * * \\
(4.07)\end{array}$ & $\begin{array}{c}6.662 * * * \\
(4.63)\end{array}$ & $\begin{array}{c}4.363 * * \\
(2.44)\end{array}$ & $\begin{array}{c}4.398 * * \\
(2.32)\end{array}$ & $\begin{array}{c}4.149 * * \\
(2.28)\end{array}$ \\
\hline Wall down & $\begin{array}{c}11.086 * * * \\
(3.68)\end{array}$ & $\begin{array}{c}9.549 * * * \\
(2.95)\end{array}$ & $\begin{array}{c}10.981 * * * \\
(3.57)\end{array}$ & $\begin{array}{l}1.563 \\
(0.45)\end{array}$ & $\begin{array}{l}4.936 \\
(1.19)\end{array}$ & $\begin{array}{l}3.241 \\
(0.87)\end{array}$ \\
\hline F (Event dummies) & $14.63 * * *$ & $14.82 * * *$ & $13.87 * * *$ & $2.67 * *$ & $3.10 * * *$ & $2.67 * *$ \\
\hline F (Administrations) & $2.39 *$ & $2.40 *$ & 2.28 & 0.63 & 0.58 & 0.70 \\
\hline $\begin{array}{l}\mathrm{R}^{2} \text { adj } \\
\text { Breusch-Godfrey } \\
\text { Heteroscedasticity } \\
\text { RESET }^{3} \\
\mathrm{~F}\left(\exp =\text { unexp }^{\mathrm{a}}\right.\end{array}$ & $\begin{array}{c}82.84 \\
0.18 \\
0.66 \\
1.20\end{array}$ & $\begin{array}{l}83.15 \\
0.23 \\
0.96 \\
0.98\end{array}$ & $\begin{array}{c}82.61 \\
0.16 \\
0.75 \\
1.23 \\
0.04\end{array}$ & $\begin{array}{c}49.46 \\
0.15 \\
2.83 * \\
1.83\end{array}$ & $\begin{array}{c}53.42 \\
5.513 * * \\
4.13 * * \\
2.61 *\end{array}$ & $\begin{array}{c}51.63 \\
0.78 \\
2.04 \\
1.24 \\
1.56 / 3.71 * \\
\end{array}$ \\
\hline
\end{tabular}

Note: $\mathrm{N}=94$. $\mathrm{t}$-values between brackets. $* * *$ significant at $1 \% ; * *$ at $5 \%$ and $*$ at $10 \%$. $\mathrm{F}$ (Event dummies) and $\mathrm{F}$ (Administrations) test joint significance of time-specific and administration-specific effects, Breusch-Godfrey and Heteroscedasticity assess autocorrelation and heteroscedasticity respectively. RESET3 is Ramsey's (1969) 
specification error test. F (exp = unexp) tests difference of the coefficients for expected and unexpected tax revenue changes.

a The first number in Column (6) is the test result for 'unified government', the second for 'divided government'. 